\title{
REGIBILINY NOTICE
}

A major purpose of the Technical Information Center is to provide the broadest dissemination possible of information contained in DOE's Research and Development Reports to business, industry, the academic community, and federal, state and local governments.

Although a small portion of this report is not reproducible, it is being made available to expedite the availability of information on the research discussed herein.

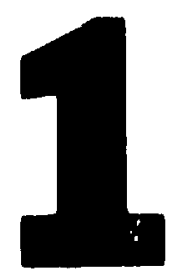




\section{$\operatorname{CONF}-8500128-2$}

TITLE MIXED-MODE FRACTURE OF CERAMICS

AUTHOA(S) J. J. Petrovic

SUBMITIED TO FOLIRTH INTERNATIONAL, SYMPOSIUM On the FRACTURE MECHANICS OF CERAMICS, Virginla Polytechnic Ingtitute and State University, Blackburk, VA June $19-21,1985$

\section{DISCI.AIMFR}

This report was prepured us un hccount of work smonamed by un hgency of the Inited Siales (iovernment. Neilher the I/nited Simles (iovernment nor any apency thereof, nor any of their cmployeen, makes any waran'y, express or impliod, or usumen uny legal linbilily or renponnihility for the accuracy, compleieness, or usefulness of any information, upparalus, produci, or

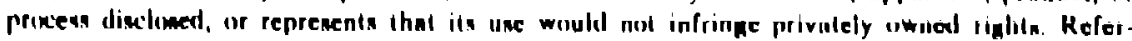
ence herein lo any apecilic commercial, product, prixesh, of nervice by irnde nume, Irndemark.

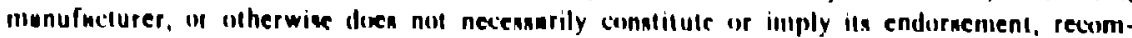
mendation, or fuviring hy the I Inited Simles fiuvernment or any agency thereof The viewn and opinions of euthors expreaned herein do not necessarily sinic ur reflect thime of the Inited Sintes (iovernment or any npency thereor. 
MIXED-MODE FRACTURE OF CERAMICS

\author{
J. J. Petrov1c \\ Materials Sclence and Technology Division \\ Los Alamos National Laboratory \\ Lo8 Alamos, New Mexico 87545
}

ABSTRACT

The mixed-mode fracture behavior of ceramic materials ts of 1mportance for monolithic ceramics in order to predict the onset of fracture under generalized loading conditions and for ceramic composites to describe crack deflection toughening mechanisms. Experimental data on surface flaw mixed-mode fracture in varlous ceramics indicate that the flaw-plane normal stiess at fracture decreases with increasing in-flawplane shear stress, although present tata exhibit a falrly wide range in detallo of th1s o - T relationsh1p. Fracture from large cracks suggests that Mode II has a Breater effect on Mode I fracture than Mode III. A comparison of surface flaw and large crack mixed-mode I-II fracture responses indicates that surface flaw behavior 16 influenced by shear resistance effects.

\title{
INTRODUCTION
}

The wixed-mode fracture behavior of fracture-initiating flaws in ceramic materials 18 of importunce for two reasons. F1rat, this 18 the necessary jasis of realist1c, physically-based multiaxial loading fracture criterla for monolithic ceramics with atatictical flaw distribution $(1,2)$. Secondly, surh behavior 18 intimately related to crack deflection toughening mechaniums in ceramic composites (3). The purpose of the present paper 18 to review experimental mixed-mode fracture results for ceramics and other brittle materials, and to compare these results to the predictions of present theoretical mixed-mode fracture criteria in order to determine their applicability.

\section{MIXED-MODE FRACTURE THEORIES}

The three Modes of fracture re hlown in F1gure 1. Mode I, the open1ng mode, exh1b1is crack aurface displacements perpendicular to the crack plene. Mode II, the 11 ding mode, exhibits crack eurface displacemente in the plane of the crack and perpendicular to the crack front. Mode III, the tearing mode, exhlb1ts crack ourface displacements also in the plane of the creck but parallel to the crack front. Generallzed loading conditions will Involve combined Modes 1,11 , and 111 . The different fracture Modes produce different stress dintributions in the 
materlal ahead of the crack t1p, the Intensity of which are governed by the otress intensity factors $K_{I}, K_{11}$, and $K_{111}$.

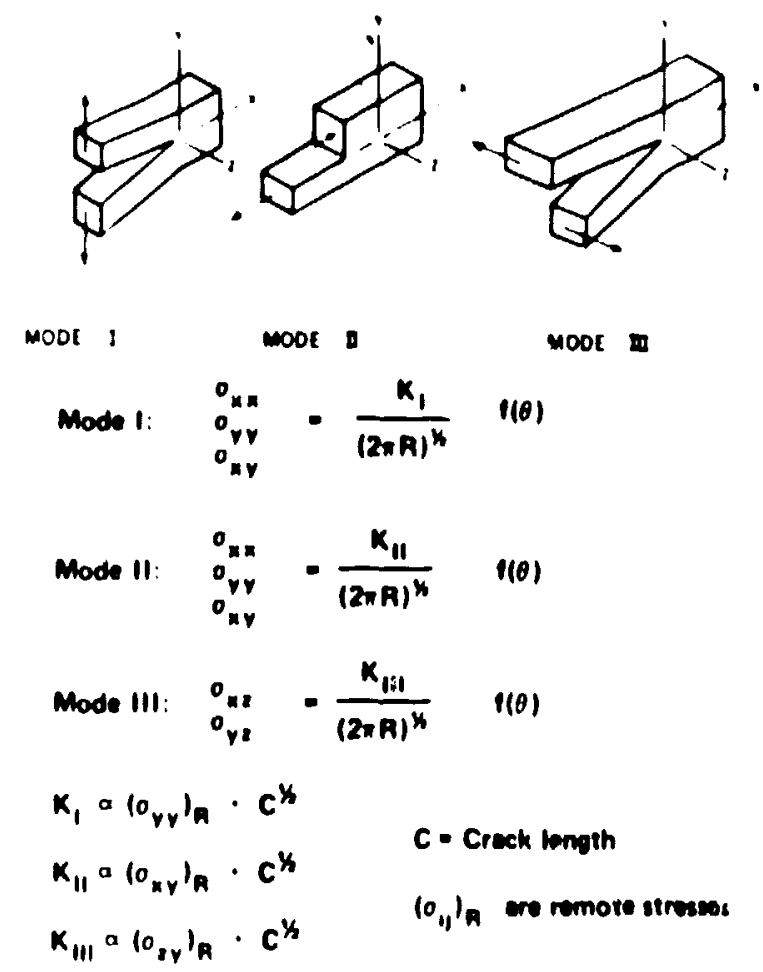

FIGURE 1: The Three Modes of Fracture.

The simplest mixed-wode fracture criterion is the coplanar criterion (4). This criteition assumes that mixed-mode fracture will inftiate, with crack extension in the plane of the initial crack, when the otrain energy release rate in this plane reaches a critical value (this critical value Is taken to be a material parameter equal to the pure Mode I crit1cal otrain energy release rate). However, coplanar mixed-mode fracture 18 virtually never observed and o non-coplanar etrain anergy release rate criteria have been put forward $(5-10)$. In non-coplanar atrain energy release rate criteria, the mixed-mode crack is presumed to extend in the non-coplanar direction of maximum utrain energy releace rate, when this quantity reaches critical value. Two other criteria of non-coplanar mixed-mode fracture are the muximum tangential tenalle etrans theory (11) and tice strain energy density theory (12). The maximum tangential tensile etress theory assimes that crack axteneion etarte in the plane perpendicular to the direction of greatest crack tip tangential capeion $o_{\theta}$, with catastrophic frecture occurring when the quantity $(2 R)^{2} \sigma_{\theta}$ raches a critical value. It 10 Interesting co note that the otratn - nergy release rate theory of Nulamer (6) ylelds the one predictions as the maximum tangential tenalle etress theory. The otrain energy deneity theory anaumes that crack initiation will atart in a radial diraction along which the etrain energy denelty is minimum, with fracture occurring when the etrain energy deneity factor reaches a critical value.

The predictions of a number of these criterie for mixed-mode I-II fracture are whom in Figure 2. These theorles predict that $\mathrm{K}_{1}$ decreases 
with Increasing $K_{I I}$. It ohould be noted that these criteria aloo predict values of the ratio $\mathrm{K}_{\mathrm{IIC}} / \mathrm{K}$ IC for the case of pure Mode 11 fracture. For the various alxed-aode fracture theorles, the range of predictions 18 $0.63 \leq K_{I I C} / k_{I C} \leq 1.02$.

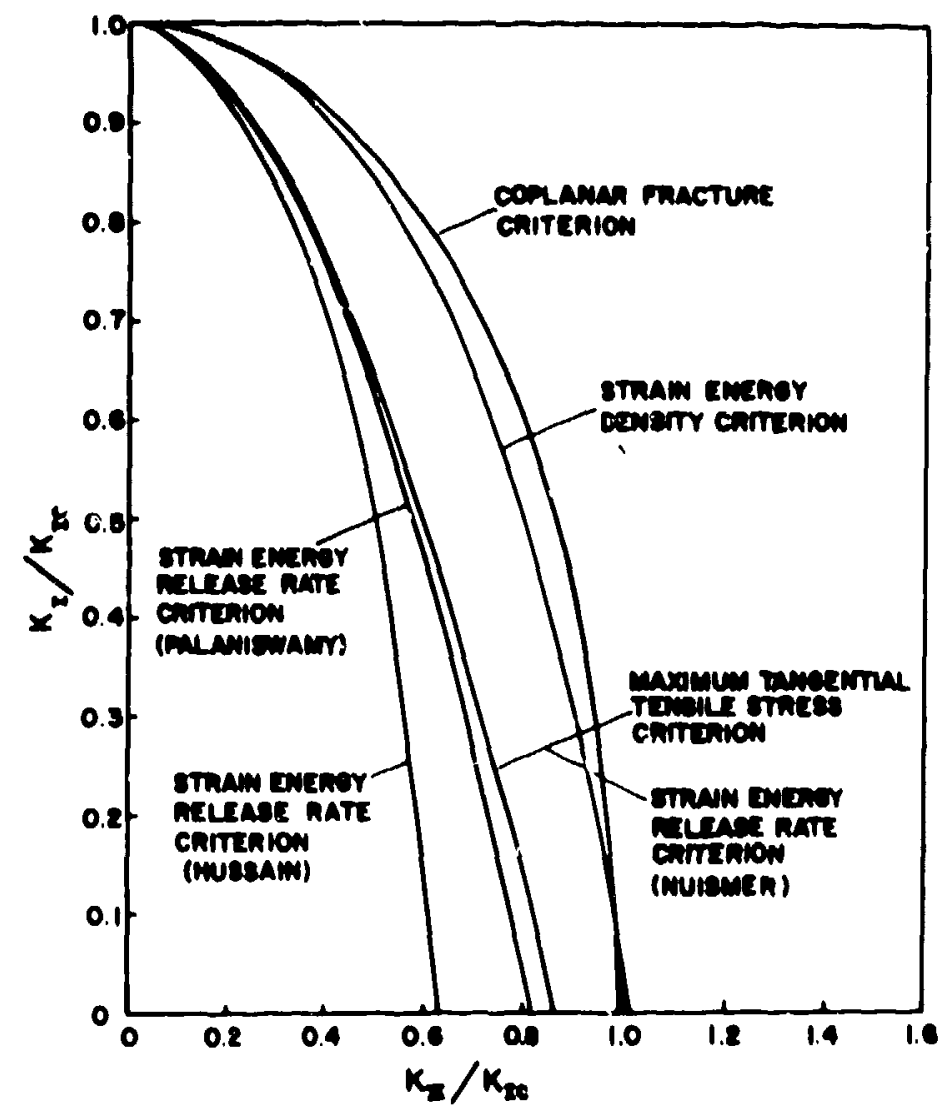

FIGURE 2: Predictions of Theoretical Mixed-Mode Fracture Criteria.

\section{EXPERIMENTAL MIXED-MODE FRACTURE RESULTS}

\section{Indentation Surface Flaws}

The mixed-mode fracture of ceramics has been examined largely using Indentation surface flaws under varlous loading configurations. Experimental results of all studies to date are summarized in Figure 3 . A key for the experimental data 18 given in Table 1. In Figure 3, $0 / 0$ is plotted versus $T / \sigma_{0}$, where $o_{1}$ the otress normal to the flaw plane, $t$ 1s the ahear etress in the plane of the flaw, and $o_{0} 18$ the fracture etrese under pure Mode I conditions.

Except for one data point, the data in Figure 3 indicate that 0 /o at fracture decreases with Increasing $T / \sigma$. Th1 means that ourface Plaw fracture 1o influenced by the presence of an in-flaw-plane shear utress. If thio were not the cane, $o_{n} / \sigma_{0}$ would equal one, Independent of the 


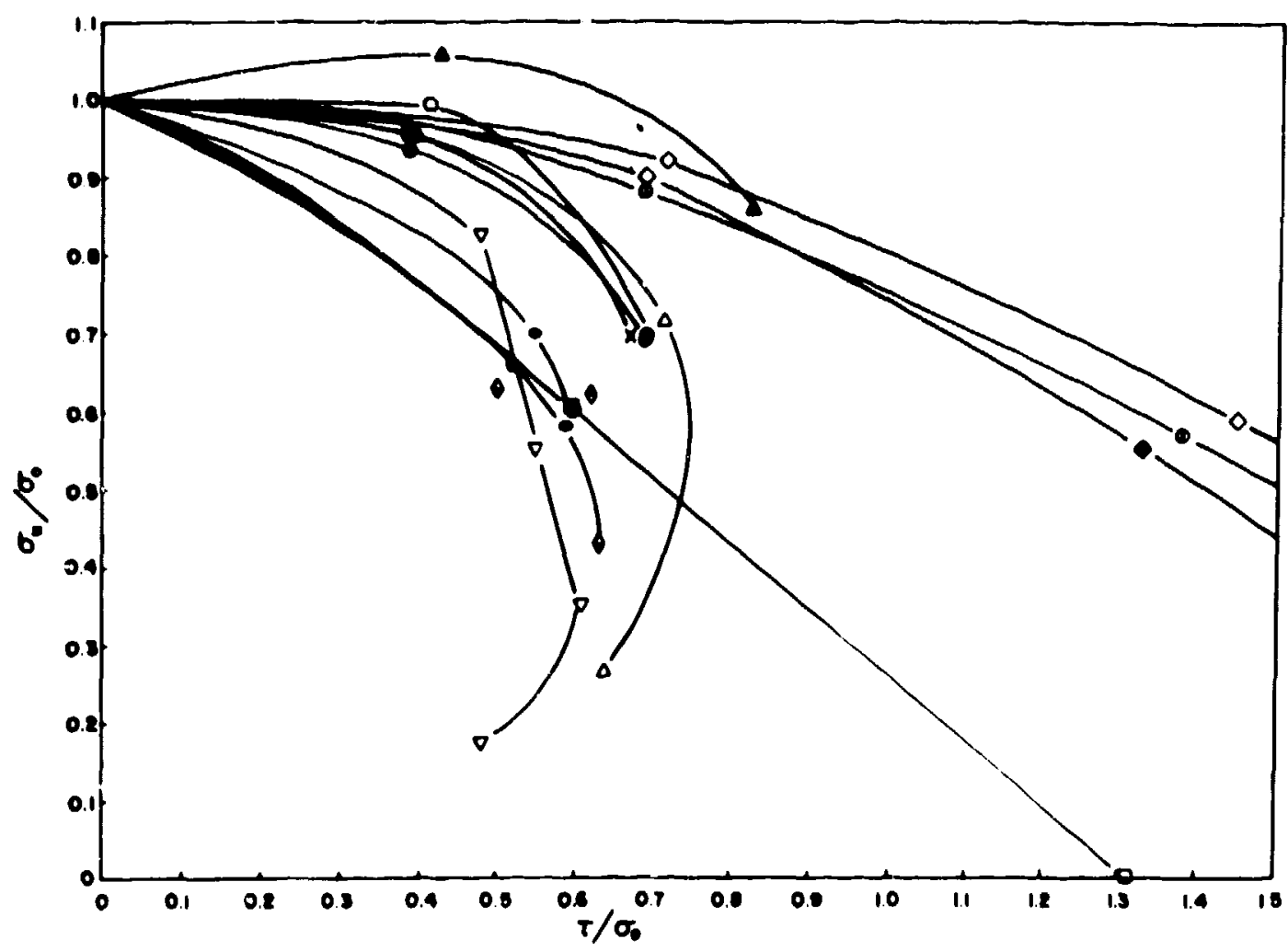

FIGURE 3: M1xed-Mode Fracture Results for Indentation Surface Flaws.

value of $T / 0$. The data in Figure 3 clearly demonstrate that a constant normal stress criterion for fracture will be serlously in error, end that the fracture criterion must include mixed-mode loading conditions.

The data in Figure 3 for varlous ceramic materials and loading conflgurat1ors exh1b1t a falrly wide range, rather than ly1ng on aingle curve. Most of the data comes from the fracture of Inclined surface f saws in bending $(13,14,15,17,18,19,20)$. Even within this single loading configuration, the data epread is sig.1ficant. At very steep angles of Inclination to the bending tennile otress, both $\sigma$ and $t$ exhlbit decreases at flaw fracture, which usually occurs only from the surface tip of the knoop Indentation.

The fllled data points in Figure 3 indlcate surface flaws which were an iealed to remove indentation residual stresses prior to mixed-mode fracture. Marahall (17) has shown that the presence of these residual otresses leads to etable non-coplanar crack growth prior to cataetrophtc fracture under med-mode loading conditions. Th1s change in crack ohape might be expected co complicate the local mixed-mode fracture altuation. However, the data in Figure 3 do not provide a clear-cut description of realdual stress effects on mixed-mode fracture, with some date ohowing significarit effects on $\sigma_{n}$ and $t$ at fracture and other date showing little effect.

Mixed-mode fracture tudies of surface flaws heve been perforeed in comblned tension/torsion $(16,19)$ and diametral compreseion (18). For 
TABLE 1. Key for Indentation Surface Flaw Mixed-Mode Fracture Reoulte in Figure 3

\begin{tabular}{|c|c|c|c|c|}
\hline Sye. Material & $\begin{array}{l}\text { Test } \\
\text { Type }\end{array}$ & $\begin{array}{l}\text { Indentation } \\
\text { Conditione }\end{array}$ & $\begin{array}{l}\text { Indentation } \\
\text { Anneal1ng }\end{array}$ & Ref. \\
\hline Hot-Pressed $\mathrm{S}_{3} \mathrm{~N}_{4} *$ & Bending & 59N Knoop & $2 \mathrm{~h} / 1200^{\circ} \mathrm{C}$ & 20 \\
\hline Hot-Pressed $\mathrm{Si}_{3} \mathrm{~N}_{4}{ }^{*}$ & Bending & 59N Knoop & None & 19 \\
\hline Hut-Pressed $\mathrm{S}_{3} \mathrm{~N}_{4}{ }^{\star}$ & $\begin{array}{l}\text { Tension/ } \\
\text { torsion }\end{array}$ & 59N Knoop & $\mathrm{lh} / 1300^{\circ} \mathrm{C}$ & 19 \\
\hline Hot-Pressed $\mathrm{SI}_{3} \mathrm{~N}_{4} \star$ & $\begin{array}{l}\text { Tension/ } \\
\text { torsion }\end{array}$ & 59N Knoop & None & 16 \\
\hline Hot-Pressed $\mathrm{SI}_{3} \mathrm{~N}_{4}{ }^{\star \star}$ & Bending & 25N Knoop & None & 13,14 \\
\hline Soda-L1me Glass & Bending & 20N Knoop & None & 15 \\
\hline Hot-Pressed $\mathrm{S}_{1} \mathrm{~N}_{4}{ }^{\star \star}$ & Bend Ing & 50N Knoop & $4 \mathrm{~h} / 1200^{\circ} \mathrm{C}$ & 17 \\
\hline Hot-Pressed $\mathrm{S}_{1} 3_{4}{ }^{* \star}$ & Bending & 50N Knoop & None & 17 \\
\hline Pyroceram 9606 & $\begin{array}{l}\text { Diametral } \\
\text { Compression }\end{array}$ & SON Knoc? & None & 18 \\
\hline Fyroceram 9606 & $\begin{array}{l}\text { Diametral } \\
\text { Compression }\end{array}$ & 50N Knoop & $4 \mathrm{~h} / 820^{\circ} \mathrm{C}$ & 18 \\
\hline A.VCO Al $2 \mathrm{O}_{3}$ & $\begin{array}{l}\text { Dlametral } \\
\text { Compression }\end{array}$ & 50N Knoop & None & 18 \\
\hline Pyroc 2ram 9606 & Bend In B & 50N Knoop & None & 18 \\
\hline Pyroceram 9606 & Bending & 50N Knoop & $4 \mathrm{~h} / 820^{\circ} \mathrm{C}$ & 18 \\
\hline AVCO $\mathrm{Al}_{2} \mathrm{O}_{3}$ & Bend Ing & 5ON Knnop & None & 18 \\
\hline
\end{tabular}

*Ceradyne $147 \mathrm{~A} \mathrm{S1} \mathrm{SN}_{4}$

**Norton $\mathrm{NC}-132 \mathrm{~S}_{3} \mathrm{~N}_{4}^{3}$

these loading configurations, fracture under pure shear conditions (1.e., zero normal stress on the flaw plane) 18 possible. For as-1ndented flaws in hot-pressed $\mathrm{Si}_{3} \mathrm{~N}_{4}$, the author obtalned a value of $1 / 0=1.31$ for this conaltion of surface flaw fracture, although thls value may have been lufluenced by non-coplanar stable crack extension prior to catastrophic fallure in pure toralon. Shetty et 1 . (18) report $T / 0$ values in pure ahear of 2.0-2.2 for Pyruceram 9606 and $\mathrm{Al}_{2} \mathrm{O}_{3}$. They have also Indicated a - Ipuificant difference in the dependence of $\sigma / 0$ on $T / \sigma$ between diametral compression and bending which they ascrlec to stress-state effect.

\section{Large Cracks}

The only large crack mixed-mode fracture dat presently avallable for a ceramic material are hown in Figure 4. In this investigation (20), the Mode I-II fracture of hot-pressed $\mathrm{S}_{2} \mathrm{~N}_{4}$ was examined using c1rcumferentially slotted tubes in combined tention/torsion, while Mode 
1-1II fracture was studied ueing circumferentially notched rods in combined tension/torsion.

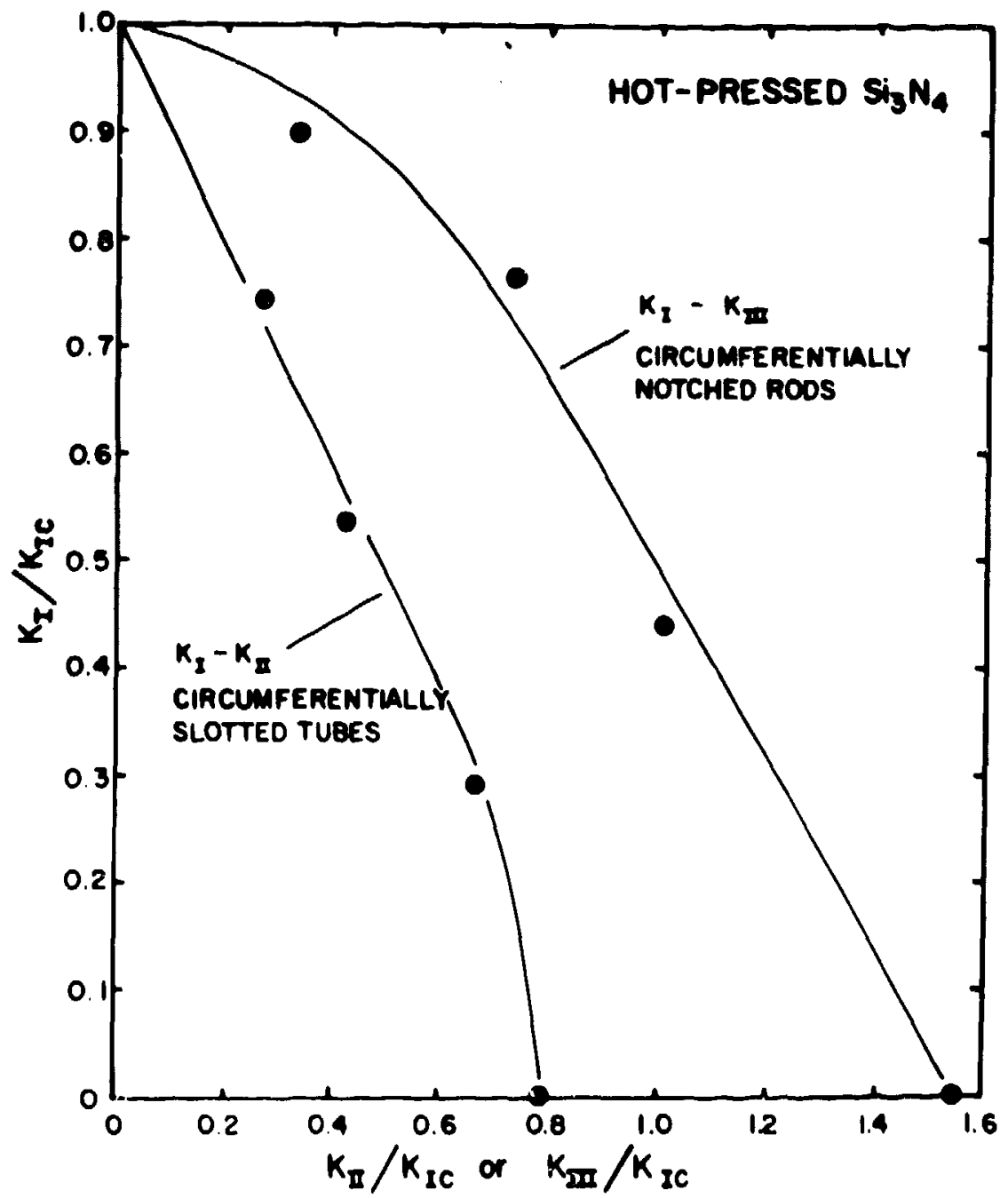

FIGURE 4: Mixed-Mode Fracture of Large Cracks in Hot-Pressed $\mathrm{SI}_{3} \mathrm{~N}_{4}$.

As may be seen in Figure 4, both Mode II and Mode III Influence Mode I fracture, with Mode II conditiono having a greater influence. Ueda et a1. (21) have observed simllar trends for the mixed-mode fracture of brittle polymethylmethacrylate (PMMA). Observed stress intensity factor rat108 in $\mathrm{SI}_{3} \mathrm{~N}_{4}$ for pure Mode II and pure Mode III loading were $K_{I I C} / K_{I C}-0.79$ and ${ }^{3} K_{I I I} / K_{I C}=1.55$. For the mixed-mode fracture of these Iarge cracks, non-planaf fracture was untversally observed, as has also been the case for atiface flawi. The theoretical non-coplanar fracture theorles almost unfvereally predict $\mathrm{K}_{I I C} / K_{I C}$ and $\mathrm{K}_{I I I C} / \mathrm{K}_{I C}$ rat 108 lese than one $(20)$.

W1th regurd to large crack etudies on other brictle materiala, Awaj1 and Sato (22) have reported $K_{1} / K_{1 c}$ rat1oe in the range of 1.09-1.16 using Inclined large cracks In diametral compreseion for graphite,

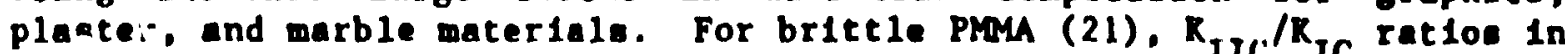
the range of $0.75-0.9$ and $K$. $/ K$ ratios of 0.98 havil bed observed. In metale, various atudies $(23-26)$ have Indicated $K_{I I C} / K_{I C}$ rat Ios in the

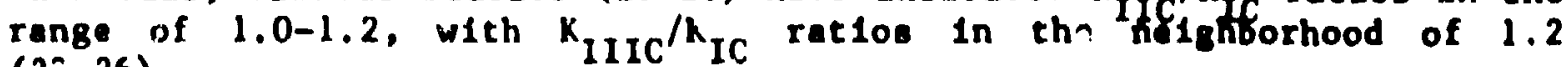
$(23,26)$. 
Figure 5 compares experimental values of $k_{I} / K_{I C}$ versus $K_{I I} / K_{I C}$ for circuaferentially elotted tubes and annealed knoop ourface Ilows in hot-preseed $\mathrm{Si}_{3} \mathrm{~N}_{4}(20)$. Also shown for comparison are a number of

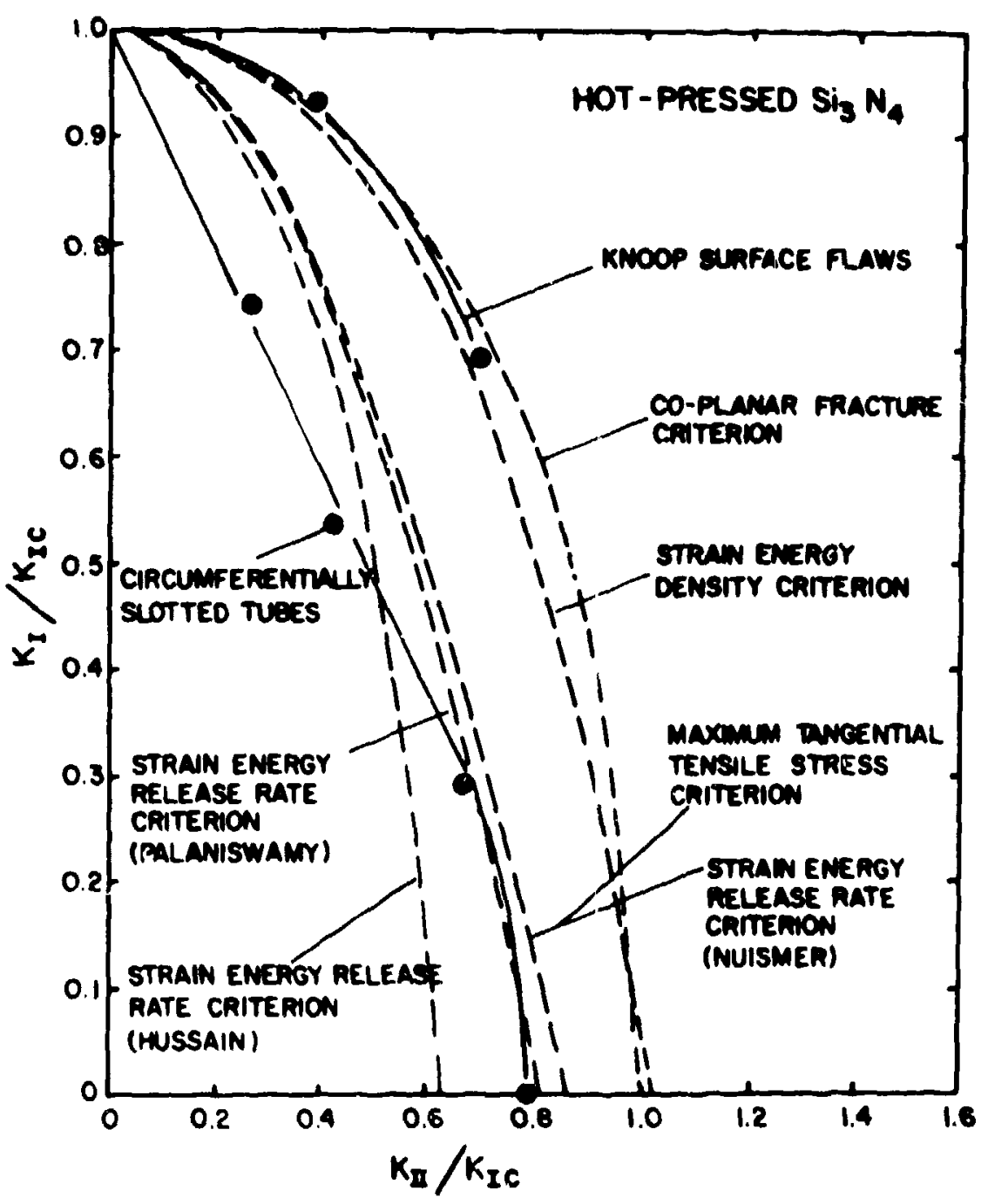

FIGURE 5: Comparison of the Mixed-Mode Fracture of Circumferentially Slotted Tubes and Annealed Surface Flaws in Hot-Pregised $\mathrm{S}_{3} \mathrm{~N}_{4}$

mixed-mode fracture criteria. As may be seen, the mixed-mode fracture data for circumferentially slotted tubes and Knoop surface flaws do not colncide. In general, the surface flaw data exhibits less of an effect of $K_{I I}$ on $K_{1}$ fracture than does the slotted tube data. While the slotted tube data are best described by predictions of the non-coplanar atrain energy release rate $(5,6,8)$ and maximum tangential tensile stress (11) criteria, the surface flaw resulta are best described by the coplanar fraceure (4) and otrain energy density (12) criterla. Prevlous investigations $(14, i 7)$ have 180 indicated that the mixed-mode fracture of aurface flaws 18 well described by the coplanar fracture criterion, this deaplte the fact that the fracture response 18 clearly non coplanar. 


\section{D). SCUSSION}

The difference in the wized-mode responses of large cracks and surface flaws shom in Figure 5 is of some insight. Marahall (17) hes suggested that aurface flaws which are free of Indentation residual streses (1.e., annealed flaws) have crack ourfaces that are In contact at asperities. This resistance to shear at the contact points would reduce the effectiveness of the applied shear loading in producing etrese Intensification at the crack $t 1 p$, thus effectively reducing the actual $K_{I I}$ level for surface $f$ laws under mixed $K_{I} / K_{I l}$ loading below that calculated under the assumption that the surfaces were not in contact. Since the large crack ourfaces were not in contact, this would account for the difference in Figure 5 .

In a recent study (20), this effect has been modeled by assuming thet the in-flaw-plane shear stress for surface flaws 18 reduced by a multiplicative factor related to the surface roughness and crack opening displacement of the flaw, termed the shear resistance factor $S_{\text {. This }}$ factor ranges between zero (complete crack resistance to silding displacements) and one (no crack resistance effects). A l1kely functional form for the shear resistance factor 16 the ratio of the surface flaw crack opening displacement (COD) to the average asperity height d. Using the expression of Sneddon (27) for the elast1c crack opening displacement of a penny-shaped flaw in an Inilnite medium under tensile loading, the Mode II stress intensity factor for surface flaws may be expressed as

$$
K_{I I}=\left(\frac{4}{\pi^{\frac{1}{2}(2-\nu)}}\right)\left(\frac{8\left(1-v^{2}\right) \sigma_{n} a}{\pi E d}\right)^{\tau} a^{\frac{3}{2}}
$$

where the second term represents the shear resistance factor. Here, $\sigma$ is the stress normal to the flaw plane, a 18 the flaw radius, $t$ is the applied shear stress, E Is the elastic modulus, d 18 the asperity helght, and $v$ is Polsson's ratio.

The above expression Indlcates that $k$. II for surface flaws depends on both the shear stress $T$ and the nompl stress $\sigma_{0}$. In gqdition, the flaw size dependence of $K$ becomes a rather than a 192 . Finally, the material variables of elastic modulus $E$ and asperity height d (expected to be some fraction of the material grain size) are introduced. These would suggest that ceramics with high elagtic moduil and large gralr. sizes may be the moet susceptible to shear resistance effects. Application of the above expression to mixed-mode surface flaw fracture in hot-pressed $\mathrm{SI}_{3} \mathrm{~N}_{4}$ (20) brings surface flaw responses into better correspondence with the predictions of non-coplanar otrain energy release rate fracture theories.

\section{SUMMARY}

Experimental mixed-mode fracture responses for ceramics and other britcle materials have been reviewed and compared to predictions of theoretical mixed-mode fracture criterla. Surface flaw results demonstrate a olgnificant effect of In-flaw-plane shear etreses on the flaw-plane normal stress at fracture, 1ndicating that the curface flaw fracture criterion must include mixed-mode loading conditione. Mixedmode iracture stud1es of large cracks euggest that Mode II has a greater effect on Mode I fracture than does Mode III. A comparison of aurface 
flaw and large crack mixed-mode $i-11$ fracture behavior indlcatog that ohear realstance effects influence the surface flaw mixed-mode response.

\section{REFERENCES}

1. S. B. Batdorf and J. G. Crose, J. Appl. Mech., 41:459 (1974).

2. S. B. Batdorf and H. L. Hein1sch, J. Amer. Ceram. Soc., 61:355 (1978).

3. K. T. Faber and A. G. Evans, Acta pet., 31:565 (1983).

4. P. C. Par1s and G. C. S1h, in "Stress Analysis of Cracks", ASTM STP 381, American Soc1ety for Testing and Materials (1965).

5. M. A. Hussain, S. L. Pu, and J. Underwood, in "Fracture AnalyBis", ASTM STP 560, American Soclety for Testing and Materials (1974).

6. R. J. Nulsmer, Int. J. Fract., 11:245 (1975).

7. W. T. Chiang, in "Fracture 1977", 4:135, University of Waterloo (1977).

8. K. Palan1swamy and W. G. Knauss, In "Mechanics Today", 4:87, S. Nemat-Nasser, ed., Pergamon Press, New York (1978).

9. M. Ich1kawa and S. Tanaka, Int. J. Fract., 18:19 (1982).

10. W. Shen and J. D. Lce, Eng. Fract. Mech., 16:783 (1982).

11. F. Erdogan and G. C. S1h, J. Basic Eng.. Trans. ASME, Serles D, $85: 519$ (1963).

12. G. C. S1h, Int. J. Fract., 10:305 (1974).

13. J. J. Petrovic and M. G. Mendiratca, J. Amer. Ceram. Soc., $59: 163$ (1976).

14. J. J. Petrovic and M. G. Mendtratta, J. Amer. Ceram. Soc., 60:463 (1977).

15. S. W. Freiman, A. C. Gonzalez, and J. J. Mecholsky, J. Amer . Ceram. Soc., 62:206 (1979).

16. J. J. Petrovic, in "Fracture Mechanics of Ceramics", 6:63, R. C. Bradt, A. G. Evans, D. P. H. Hasselman, and F. F. Lange, eds., Plenum Publishing Corp., New York (1983).

17. D. B. Marsha11, J. Amer. Ceram. Soc., 67:110 (1984).

18. D. K. Shetty, A. R. Rosenfleld, and W. H. Duckworth, "Blaxial Stress-State Effects on Mixed-Mode Fracture from Surface Flaws In Ceramics", submitted to the J. Amer. Ceram. Soc., (1985).

19. J. J. Petrovic, unpublished research.

20. J. J. Petrovic, "Mixed-Mode Fracture of Hot-Pressed $\mathrm{Si}_{3} \mathrm{~N}_{4}$ ", J. Amer. Ceram. Soc., June (1985).

21. Y. Uita, K. Ikeda, T. Yao, and M. Aok1, Eng. Fract. Mech., 18:1131 (1983).

22. H. Awaj1 and S. Sato, J. Eng. Mat. Tech., 100:175 (1978).

23. R. C. Shah, in "Fracture Analys18", ASTM STP 560, American Soctety for Testing and Materials (1974).

24. A. F. C. L1U, AIAA Journa1, 12:180 (1974).

25. D. L. Jones and D. B. Ch1sholm, Eng. Fract. Mech., 7:261 (1975).

26. 1. P. Pook, Eng. Fract. Mech., 3:205 (1971).

27. 1. N. Sneddon, Proc. Roy. Soc. London, Sertes A, 187:229 (1946).

\section{ACKNOWLEDGEMENTS}

Th1s work was supported by the Division of Materials Sciences, Office of Basic Energy Sclences, U. S. Department of Energy, under Contract No. W-7405-ENG-36. The author 18 grateful to M. L. Lovato for ansistance in the performance of mixed-mode fracture testing. 